\title{
Assessment of the feasibility of hybrid renewable power for supply pumping system for irrigation
}

\author{
Hicham Mhamdi *, Mohamed Ahticha, omar Kerrou, Azeddine Frimane, Mohammed Bakraoui, Mohammed Aggour
}

Laboratory of Electronic Systems, Information Processing, Mechanics and Energetics,Faculty of Sciences Kenitra, University Ibn Tofail Kenitra, Kenitra, Morocco

*Mail: hicham.mhamdi@uit.ac.ma

Postal address: Ibn Tofail University, Faculty of Sciences, University campus, BP: 133, Kenitra, Morocco Article History: Received: 11 January 2021; Accepted: 27 February 2021; Published online: 5 April 2021

\begin{abstract}
:
Crop identification is vital to make an inventory of the crops grown in a given area and their cultivation period. The Remote sensing (RS) techniques can provide information on the distribution of cultivated land, crop types, and areas for the agricultural sector's effective management.

In remote sensing, various vegetation indices (VI) can analyze and evaluate multiple phenomena and themes. The Normalized Difference Vegetation Index (NDVI) is an essential and highly significant remote measurement widely used in agriculture for phenological monitoring and crop health (Ray and Dadhwal, 2001).

In this work, we present a methodology for the contribution of NDVI from Landsat 7 (TM) and (ETM+) images to crop mapping in the Gharb region using a classification based on the pixel approach and estimating rice crop coefficient from NDVI.

The classification results concern six main types of crops planted in this region (beet, maize, sugar cane, market gardening, cereals, and rice). The classification map showed differences in agricultural practices adopted by farmers in crop spatial distribution. The classification results showed the ability of this methodology to discriminate between crops. Crop coefficients were deduced from the NDVI extracted from the images. Due to meteorological data collected from the meteorological station TCSC of SK Tlet, the estimation of the reference evapotranspiration was made and subsequently the potential evapotranspiration of each crop during the agricultural season 2019-2020.

The highest values for ETC were obtained when the crop was in its full development when water was mainly lost through transpiration after a slight decrease in the ratio values observed during the phase of the vegetative cycle (maturity).

The water requirements (daily, monthly and annual) for the crops were determined and their electrical energy consumption. Renewable energy can be an effective solution to meet the energy needs of plots, greenhouses and large farms.

A technical-economic study of different combinations of autonomous hybrid renewable energy systems (HRES) in order to meet the power supply needs of the above mentioned crops in the Gharb region. The renewable energy sources considered are solar, wind and biomass. The results show that for an average energy requirement of $92 \mathrm{kWh} / \mathrm{day}$ and a peak load of $6.5 \mathrm{~kW}$, the unit energy cost of the optimal configuration scenario A (PV-wind-biomass-battery) is 0.19 $\$ / \mathrm{kWh}$. Therefore, the design, development and implementation of the proposed system is a promising solution for the security of energy supply. For a 100\% integration of renewable energy, the HRES produces electricity according to the following distribution: $11 \%$ from wind, $41 \%$ from solar and $48 \%$ from biomass.
\end{abstract}

Keywords: Remote sensing, Evapotranspiration, NDVI, Crop coefficient, Hybrid System, Feasibility, HOMER.

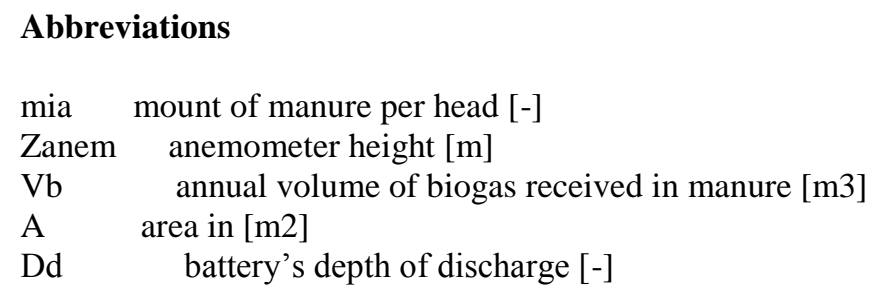




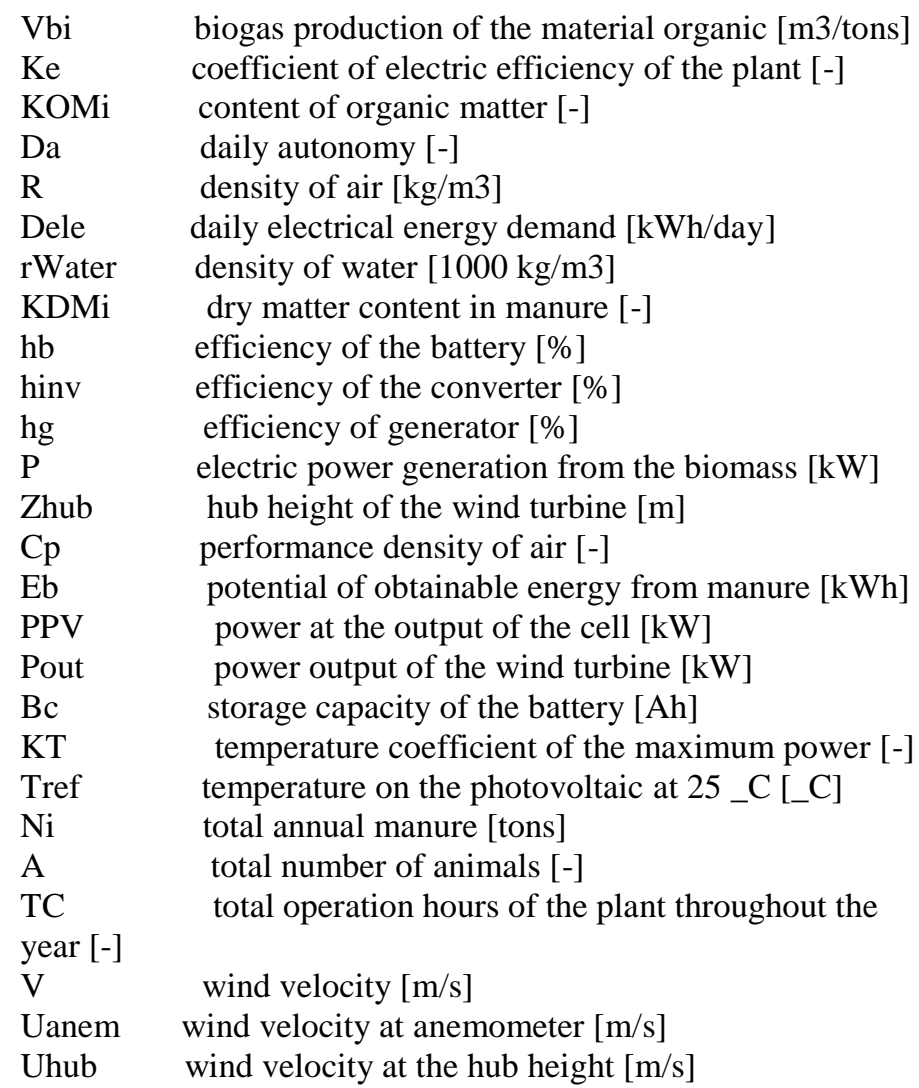

\section{Introduction}

Agriculture is a vital and crucial element in the economy of the Gharb region. To ensure efficient management of agriculture, geospatial data and statistics are indispensable. However, traditional data collection techniques are expensive and unsuitable for monitoring seasonal crop development. The RS allows the mapping of crop types by monitoring their seasonal development using multidate images covering the crop growing cycle.

The use of RS for crop identification in semi-arid areas is significant and useful [5].

Several research projects have been conducted to monitor the evolution of the crop growing cycle and evaluate crop yields using RS combined with modeling approaches (Bastiaansen and al. i 2003; Doraiswamy and al.. 2004; Inoue and al.. 2008, etc.). [6] These models simulate the entire crop cycle's biophysical processes, considering as many components of the soil, the atmosphere, etc. description of crop growing (Doraiswamy et al. 2004). [9]

Research has shown a good simulation of crop coefficients derived from VI from multispectral images (Hunsaker et al., 2003). [15]

Several researchers (Allen and al.. (2011)), Hunsaker and al.. (2005), Gonzalez-Dugo and al.. (2009) have studied and defined the correlation and the best possible relationship between the crop coefficients of multispectral NDVI images based on the vegetation surface's reflectance. The VI allows bio-physical parameters to emerge from multispectral images using empirical equations. The VI can be used to define and monitor different crop parameters. [20]

Different formulae were developed to estimate evapotranspiration; there are formulae based on energy balance (Penman, 1948; Allen and al.., 1998b; Nouri and al.., 2013) [18], formulas referring to the air temperature (Thornthwaite, 1948; Blaney, 1952) [19].

The FAO-56 PM equation is more accurate in ETO estimation because it uses many parameters and is the most widely used formula for estimating evapotranspiration in agriculture (Allen and al.., 1998b; Allen, 2000).

Many research studies have been carried out on estimating Kc values for vegetable crops (peas, onions, and tomatoes) $[26,22]$.

Researchers have revealed that VI extracted from satellite images can be used to estimate crop coefficients. [24-25-29]. 


\section{Materials and methods}

\subsection{The region of study}

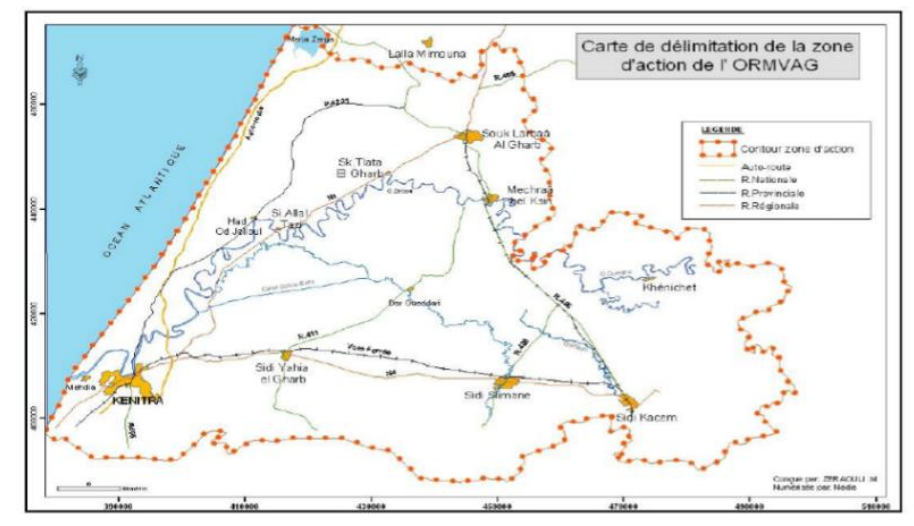

Figure 1 : The region of Gharb

The region of Gharb constitutes one of Morocco's most important agricultural perimeters, with a surface area of 116 000 ha. The perimeter is experiencing a real dynamic concerning the transition to drip irrigation.

\subsection{Meteorological data}

All meteorological data were collected from the TCSC weather station located in SA TAZI. The data are temperature $\left(\mathrm{T}_{\max }, \mathrm{T}_{\min }, \mathrm{T}_{\text {average }}\right)$, wind speed, net radiation, relative humidity, and reference evapotranspiration during the season 2019-2020.

The rice crop evapotranspiration was estimated by in situ lysimetric measurements per decade for the growing season 2019-2020.

\subsection{Penman Monteith equation}

The FAO-56 PM formula is expressed by the following equation : [1]

$$
\mathrm{ET}_{\mathrm{O}}=\frac{0.408 \Delta\left(\mathrm{R}_{\mathrm{n}}-\mathrm{G}\right)+\gamma \frac{\mathrm{C}_{\mathrm{n}}}{\mathrm{T}+273} \mathrm{U}_{2}\left(\mathrm{e}_{\mathrm{s}}-\mathrm{e}_{\mathrm{a}}\right)}{\Delta+\gamma\left(1+\mathrm{C}_{\mathrm{d}} \mathrm{U}_{2}\right)}
$$

Where :

$\mathrm{ET}_{\mathrm{O}}=$ reference evapotranspiration $(\mathrm{mm} / \mathrm{day})$

$\mathrm{R}_{\mathrm{n}}=$ crop's net radiation surface $(\mathrm{MJ} / \mathrm{m} 2 / \mathrm{day})$,

$\mathrm{G}=$ soil heat flux density $(\mathrm{MJ} / \mathrm{m} 2 /$ day $)$,

$\mathrm{T}=$ mean daily air temperature ( $2 \mathrm{~m}$ height $)$,

$\mathrm{u}_{2}=$ wind speed at $2 \mathrm{~m}$ height $(\mathrm{m} / \mathrm{s})$,

$\mathrm{e}_{\mathrm{s}}=$ saturation vapor pressure $(\mathrm{kPa})$,

$\mathrm{e}_{\mathrm{a}}=$ actual vapor pressure $(\mathrm{kPa})$,

$\Delta \quad=$ slope vapor pressure curve $(\mathrm{kPa} / \mathrm{C})$,

$\gamma \quad=$ psychrometric constant $(\mathrm{kPa} / \mathrm{C})$.

The FAO-56 PM equation requires standard climatological data of solar radiation, humidity, air temperature, and wind speed. [16]. All the meteorological data were recorded at the $2 \mathrm{~m}$ elevation point. 


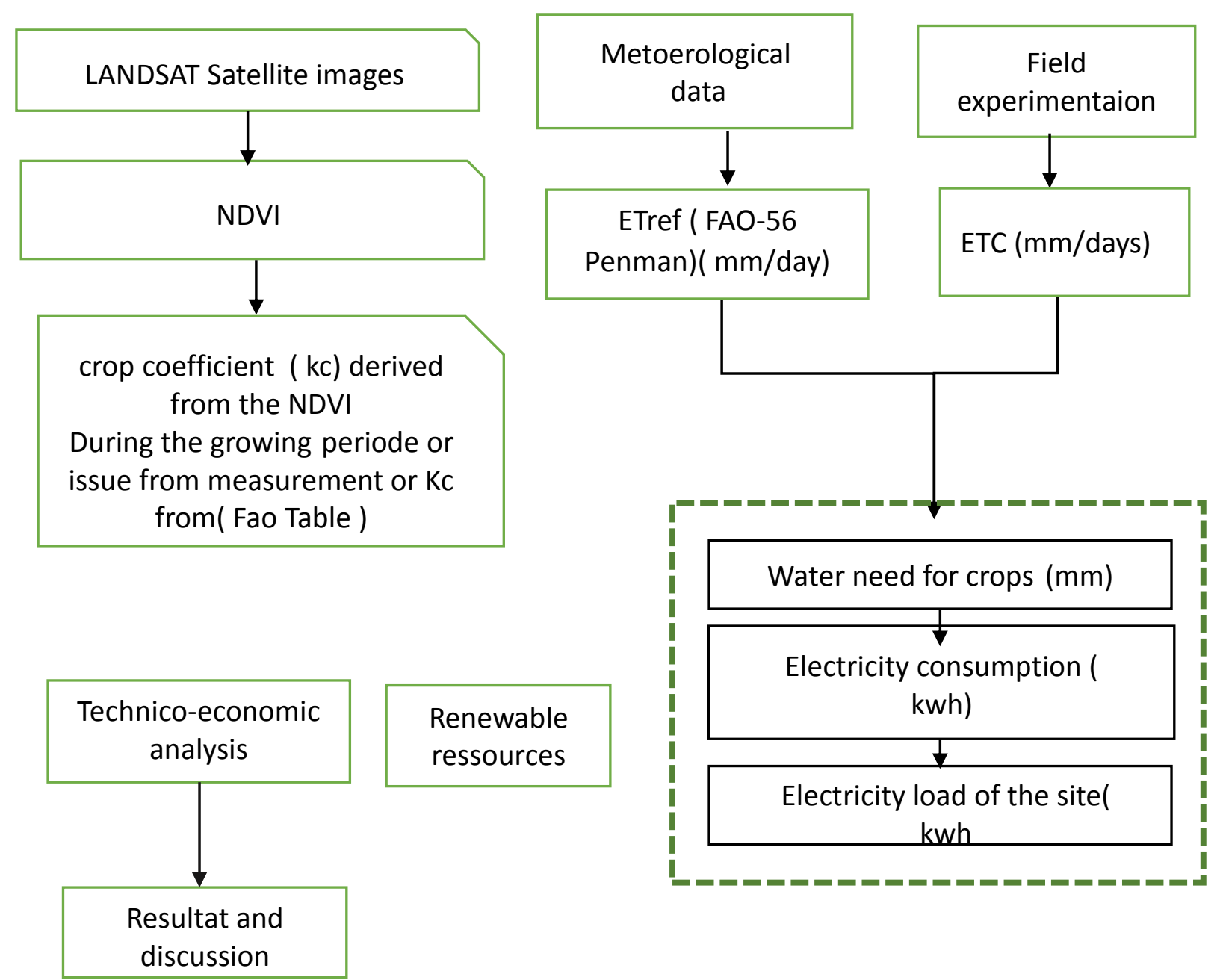

Figure 2 : THE METHODOLOGY FLOWCHART

\subsection{Estimation of crop evapotranspiration :}

The following formula expresses crop evapotranspiration:[2]

$$
E T C=E T O * K C
$$

ETC is the potential evapotranspiration of the crop, and $\mathrm{Kc}$ is the crop coefficient; it is a parameter that depends on the crop's growth stage. The crop coefficient indicates various environmental factors and the influence of the crop on evapotranspiration. Multiple comparisons of $\mathrm{ET}_{\mathrm{O}}$ and $\mathrm{Kc}$ measurements have been provided for different locations under differing conditions. [21]

The NDVI is derived from LANDSAT 7 satellite images (TM and ETM+) for six different crop stages according to the following equation :

$$
\boldsymbol{N D V I}=\frac{\left(\mathrm{P}_{\mathrm{NIR}}-\mathrm{P}_{\mathrm{red}}\right)}{\left(\mathrm{P}_{\mathrm{NIR}}+\mathrm{P}_{\mathrm{red}}\right)}
$$

Monitoring the evolution of the growing cycle of crops and agricultural production is often carried out using VI, particularly the NDVI. 
The NDVI is the parameter that allows monitoring the evolution of the spectral response of the crop to applied irrigation rates while giving the different quality statuses of the crop (Bell and al.., 2009) [10]. The NDVI is an indicator of the chlorophyll activity in vegetation. [4]

Researches were made by ( Doorenbos and Pruitt, 1977; Allen and al.., 1998) to elaborate the Kc values of different crops during their growing cycles. [11] Kc is estimated from NDVI due to the strong relationship between the NDVI and the Kc (Ray and Dadhwal, 2001) [12].Due to the relationship between NDVI and KC, NDVI has always been considered as a parameter for monitoring and control of vegetation during its growth cycle (Justice and Townshend, 2002) [13]. High photosynthetic activity leads to high NDVI values; in contrast, high temperatures lead to low NDVI values (Boegh et al. 1999). [14]

Efficient and rational management of irrigation water requires a reliable quantitative estimate of evapotranspiration. In situ measurement of rice crop using a lysimeter is necessary for a reliable estimation of the crop coefficient's evolution over the entire period of its growth.

\subsection{Data collection}

The data used to validate classification results are the field data of the types of crops existing in the region of Gharb at the date of 14/04/2019. The data distinguishes six types of crops in addition to 3 land uses. The data presenting the crop types in plots have been divided to distinguish the data to validate the results and the characterization during the classification.

The crop identification based on phenology requires temporal monitoring during the stages of crop evolution. Crop mapping in our study was carried out for the agricultural season 2019-2020 according to field data availability.

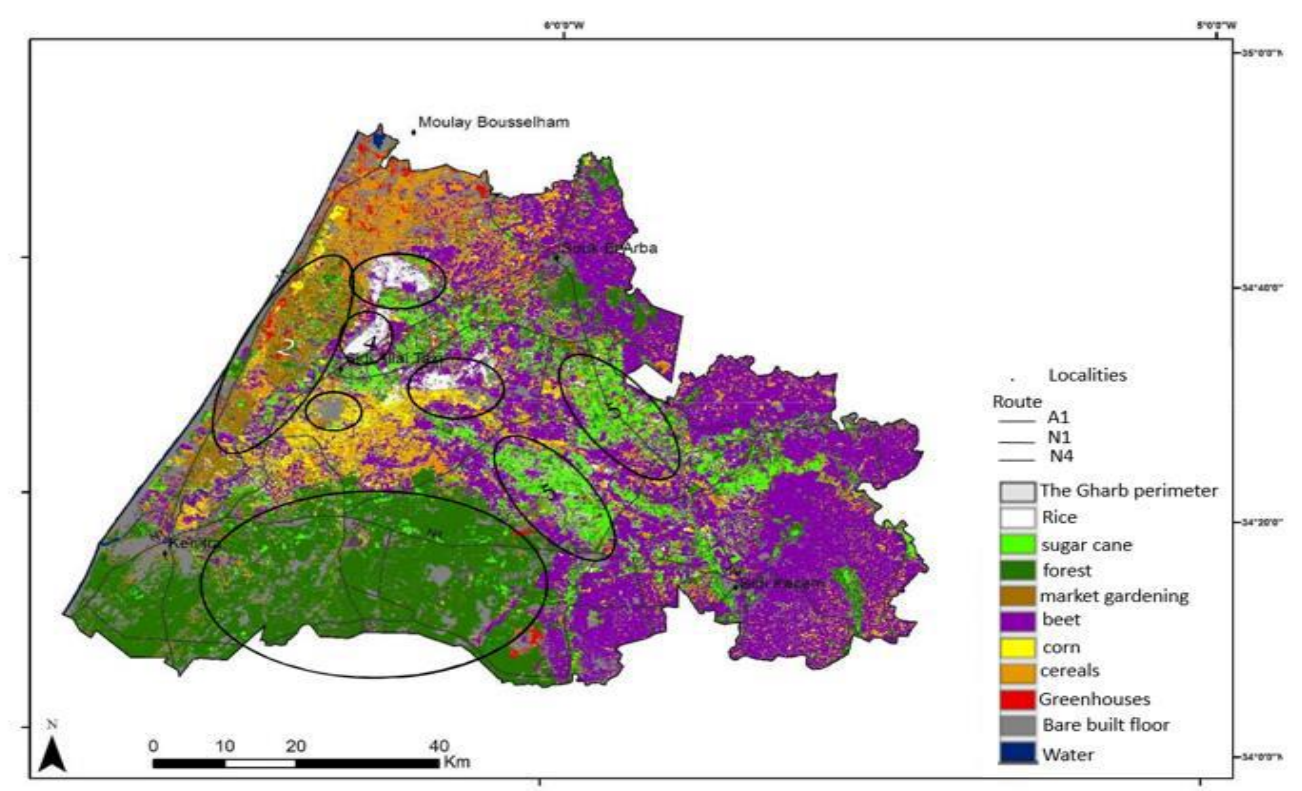

Figure 3 : Result of the SVM classification based on pixel

\section{Methodology}

The adopted methodology in this work is shown in the methodology flowchart. The proposed system is an autonomous hybrid system containing biomass generator, solar PV field and wind turbines as power generation options. A data collection and preliminary assessment of the irrigation characteristics in terms of energy demand, available energy infrastructure, current and future renewable projects underway in the region have been conducted. System configuration is determined and optimum size of each power generation technology is achieved based on the local economic and energy requirement inputs.for irrigation. ETC is defined as the process by which water is lost by evapotranspiration. (Doorenbos, 1984; Running and al.., 2017) [7].The two processes of transpiration and evaporation are simultaneous and closely related (Ding et al., 2013). [8] 


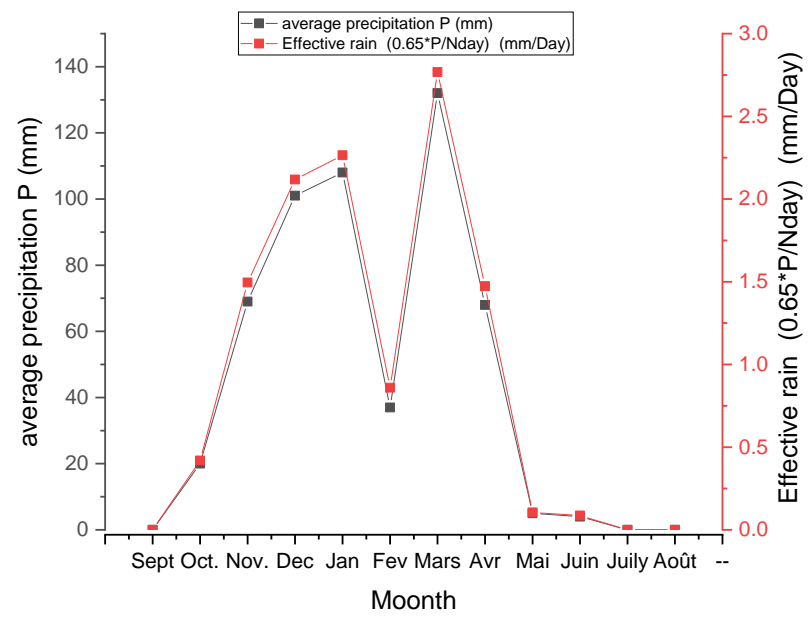

Figure 4 : Effective rain and average precipitation for the 20192020 compaigne

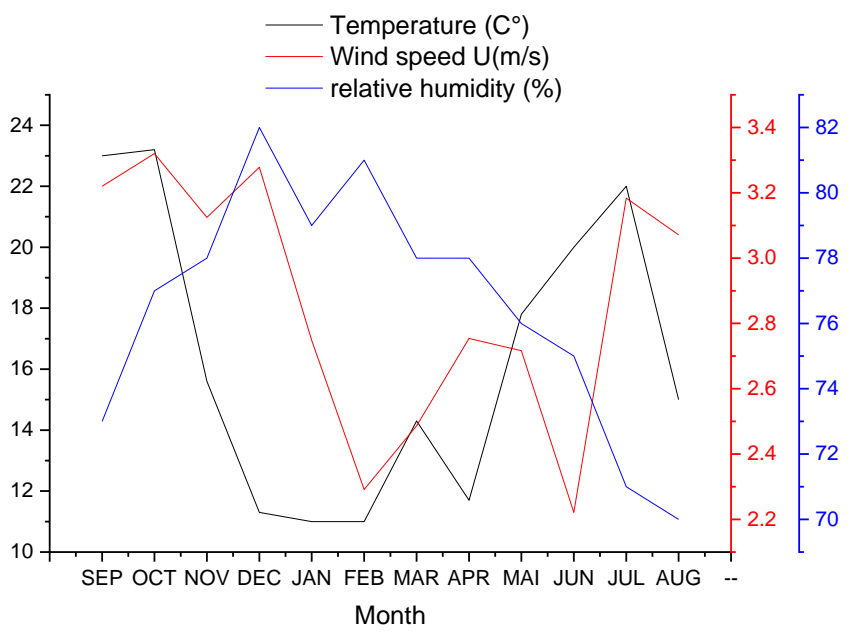

Figure 5: climatic data during the compaign season 2019-2020 


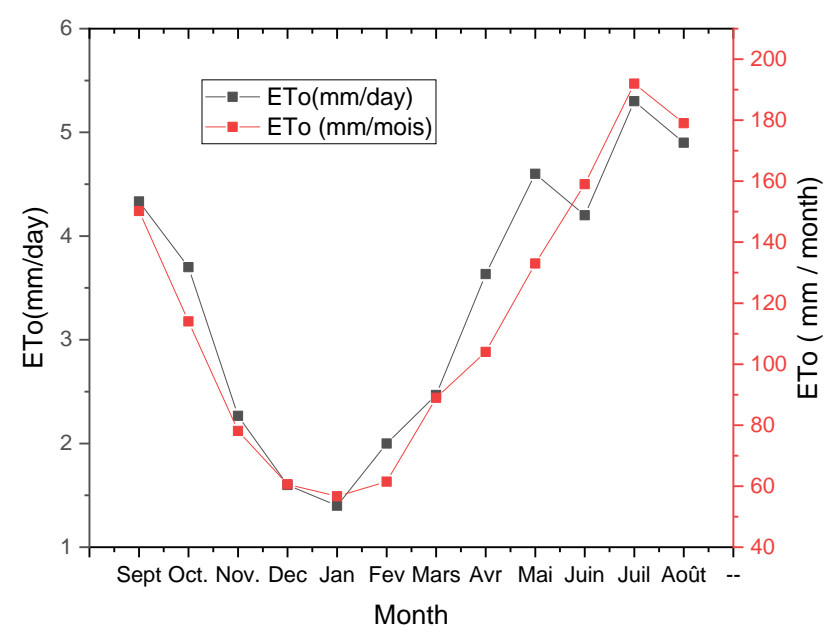

Figure 6: The reference evaptranspiration during the growing cycle( 2019-2020 season)

\section{CROP COEFFICIENTS :}

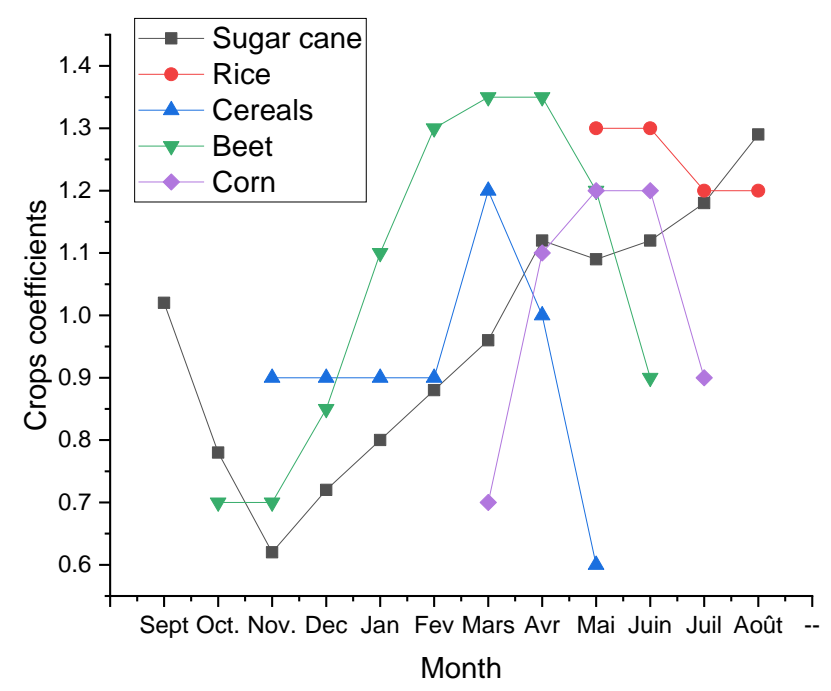

Figure 7: the evolution of corps coefficients during the growing cycle( 2019-2020 season) 


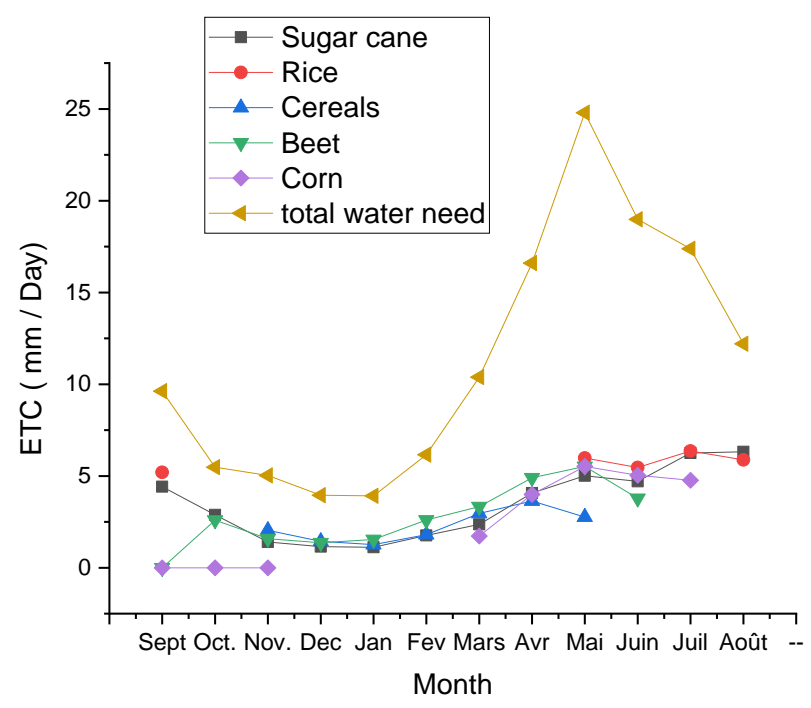

Figure 8: the daily ETC of crops during the growing cycle ( 2019-2020 season)

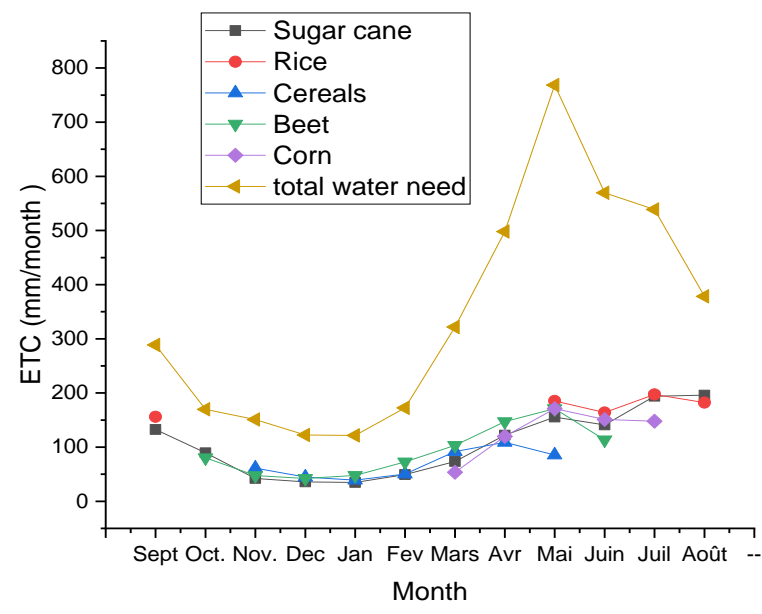

Figure 9: The monthly ETC of crops during the growing cycle (2019-2020 season)

\subsection{Load assessment}

The proposed system seems to be a promising option to supply the pumping station electricity need for irrigation purposes. The case study consists of six man crops supplied by irrigation water by pumping station connected to the electricity grid. However, the main purpose of this manuscript is to analyse the possibility of implementing centralized stand-alone HRES in similar rural area with irrigation is done traditionally due to not access to electricity network. Fig. 13 shows the distribution of the monthly electricity consumption throughout the year 2019-2020 for the six man crops on the Gharb region. A maximum of monthly consumption is seen over the months of July and August with an average value of $1891.2 \mathrm{kWh}$ and the minimum in January with the average of $1140.12 \mathrm{kWh}$.

The distribution of the average electric load per hour for the year 2019-2020 is depicted in Fig 14. A maximum load of $6.44 \mathrm{~kW}$ (at 23:00 h) is identified in the summer season. 


\subsection{Resources assessment}

The Gharb region possesses a high potential of renewable energy resources notably biomass, wind and solar. The details of these resources are covered in the following paragraphs.

\subsubsection{Solar irradiation data}

Solar energy data for the region under examination is collected from meteorological station TSGC in SK Tlet. Fig. 10 and Fig. 11 displays the daily irradiation for two typically days. The annual average solar global horizontal irradiance is $5.07 \mathrm{kWh} / \mathrm{m} 2 /$ day with maximum of $7.18 \mathrm{kWh} / \mathrm{m} 2 /$ day observed in June and a minimum of $2.74 \mathrm{kWh} / \mathrm{m} 2 / \mathrm{day}$ in December.

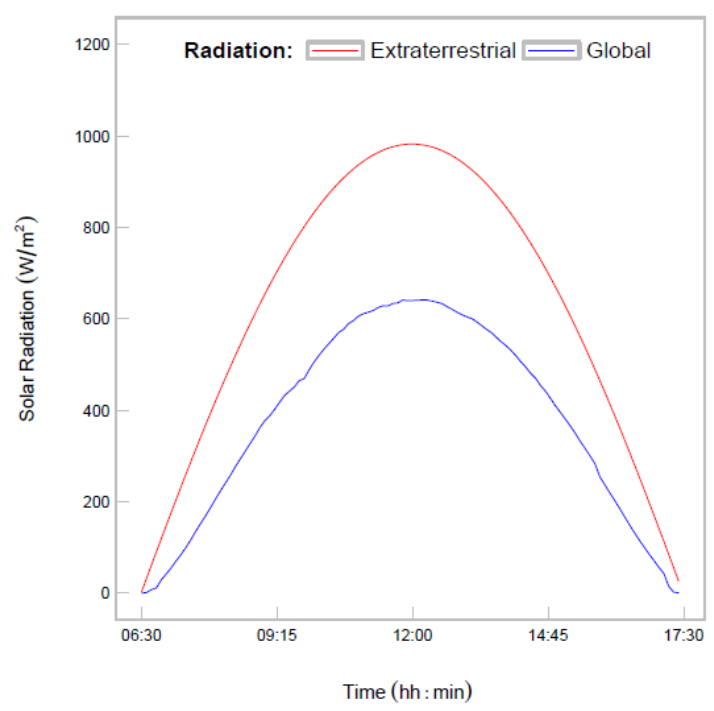

Figure 10: Solar radiation for a typical clear sky day.

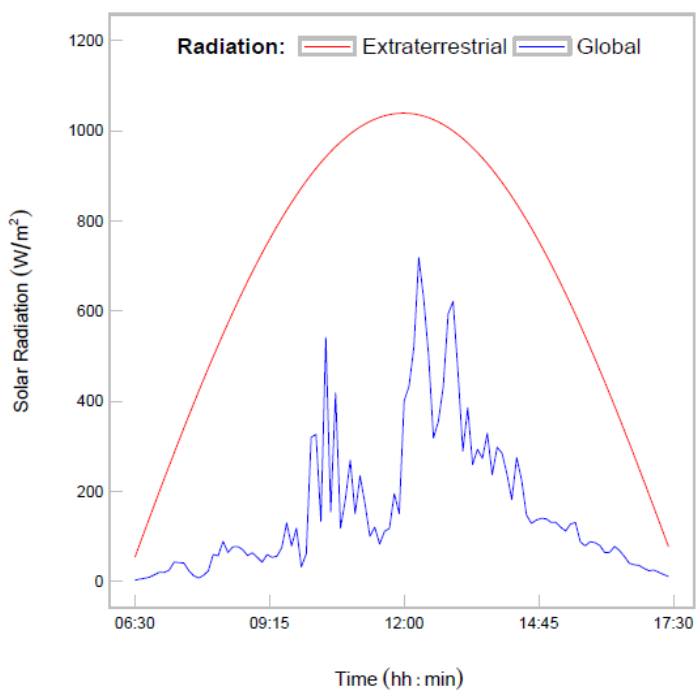

Figure 11: Solar radiation for a typical cloudy sky day. 


\subsubsection{Wind data}

The monthly mean wind speed is obtained from the meteorological station TCSG in SK tlet in Fig 5 .

\subsubsection{Biomass resource}

Biomass is among the oldest power sources in the world and through which methane $(\mathrm{CH} 4)$ and carbon dioxide $\left(\mathrm{CO}_{2}\right)$ gases are produced in the absence of oxygen by microorganisms. It is obtained from agricultural residues, animal waste, wood, and human waste etc (Zafar and Owais, 2006).

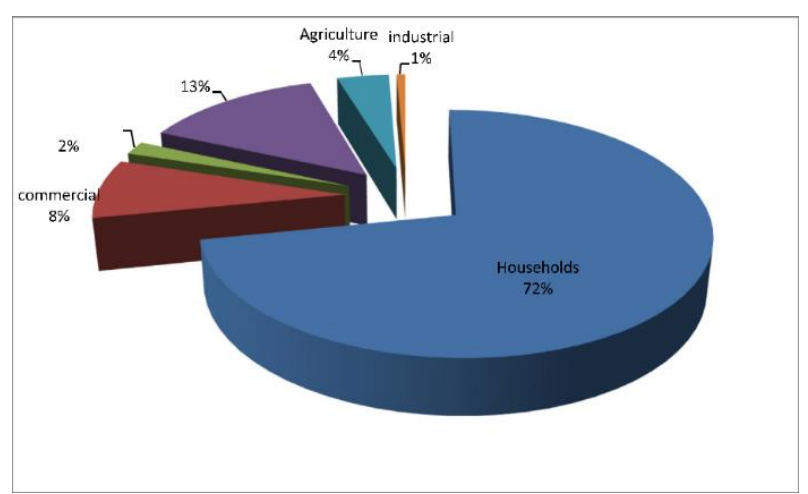

Figure 12 : Distribution of electricity consumption by sector.

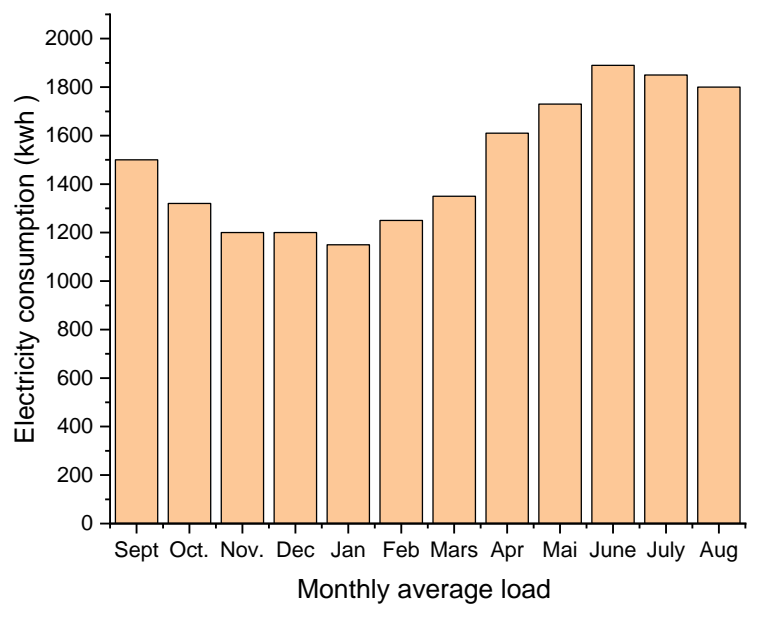

Figure 13: Monthly average load for irrigation compaign saison 2019-2020 


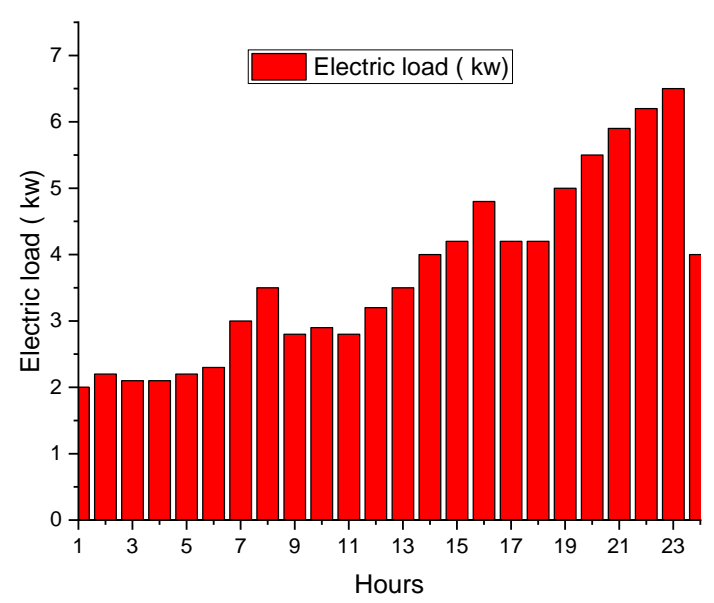

Figure 14 : Typical summer day load demand

\section{HRES detail and equipment}

The autonomous Hybrid Renewable Energy System proposed in this manuscript is illustrated in Fig. 15, which contains five major components: biomass generator, PV Modules, wind turbines, converter, and batteries for storage. 4.1. Solar photovoltaic system

The photovoltaic modules are polycrystalline silicon connected to each other, oriented towards the south and tilted at 33 , which is the optimum inclination in the studied region. Photovoltaic panels do not have a tracking system. The generating power by the PV modules is dependent on the upcoming solar radiation as well as ambient temperature. The initial price in the Moroccan market is approximately $1600 \$ / \mathrm{kW}$ and considering that the module lifespan equals to the project life and the replacement price is taken to be zero. The operating and maintenance costs are estimated at $15 \$ / \mathrm{yr}$ which is a reasonable value in the Moroccan scenario. The project lifespan is considered as 25 years. Power generated by PV modules is calculated as follows: [27]

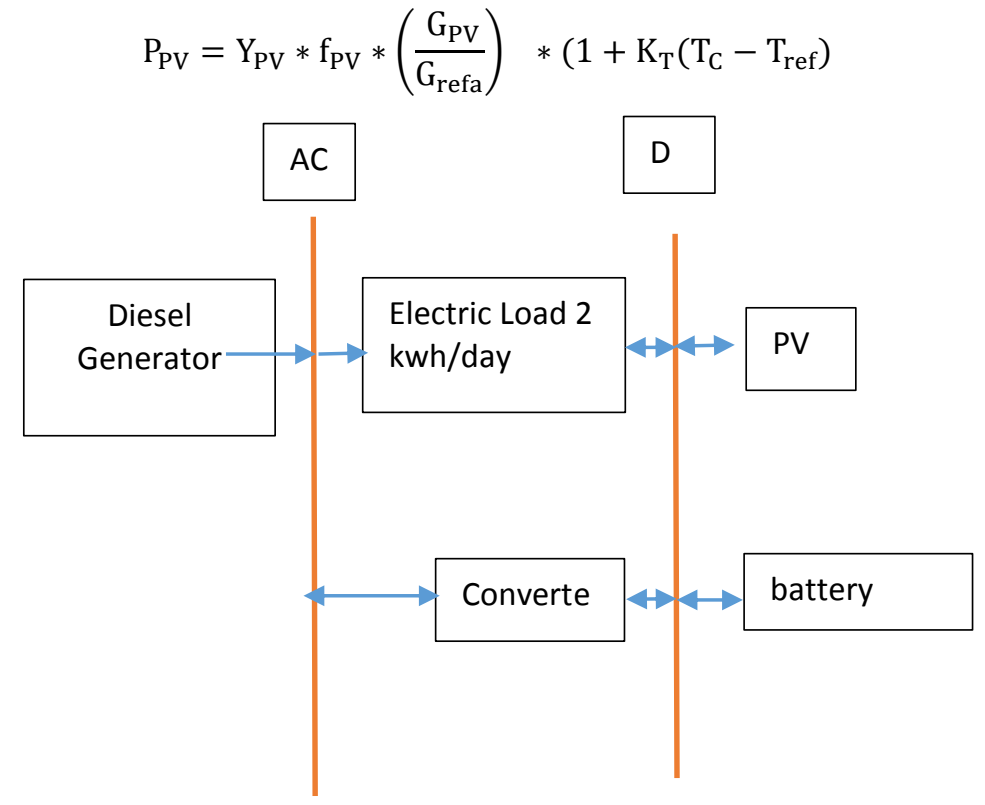

Figure 15 : Configuration of the proposed hybrid power system 
where $\mathrm{P}_{\mathrm{PV}}$ is the produced power, $\mathrm{Y}_{\mathrm{PV}}$ is the $\mathrm{PV}$ generation under standard test conditions [kW], $\mathrm{f}_{\mathrm{PV}}$ is the rated $\mathrm{PV}$ capacity [\%], GPV and Gref represent the solar energy incident on the photovoltaic field in the current time and under the standard conditions [1 kW/ m2], respectively. KT is the temperature coefficient of the maximumpower [\%/ C] and Tc and Tref are temperatures of the photovoltaic surface at standard tests conditions [25 C], respectively. The derating factor considered is around $80 \%$. In this study, the ground reflectance is equal to $20 \%$.

\subsection{Wind turbine}

The wind turbine considered in this study is of horizontal axis type, producing nominal $5.1 \mathrm{~kW}$ of AC current at the output. Technical specifications are tabulated in Table 1. The hub height of the wind turbine is $12 \mathrm{~m}$ and has a lifetime of 25 years. The wind velocity at the chosen hub height Uhub and the corresponding power output PWout are calculated using the following equations (Kennedy et al., 2017). [28]

$$
\mathrm{U}_{\mathrm{hub}}=\mathrm{U}_{\mathrm{anem}} *\left(\frac{\mathrm{Z}_{\mathrm{hub}}}{\mathrm{Z}_{\mathrm{anem}}}\right)^{\alpha}
$$

Table 1. Properties of the selected wind

\begin{tabular}{ll}
\hline Property & Specification \\
\hline Brand name & AWS-HC $5.1 \mathrm{~kW}$ \\
Rated power $(\mathrm{W})$ & 5100 \\
Rated wind speed $(\mathrm{m} / \mathrm{s})$ & $11 \mathrm{e} 25$ \\
Number of blades & 3 \\
Rotor diameter $(\mathrm{m})$ & 5.24 \\
Cut in speed $(\mathrm{m} / \mathrm{s})$ & 2.76 \\
\hline
\end{tabular}

where $U_{\text {anem }}$ represents the wind velocity at anemometer height, respectively. $Z_{\text {hub }}$ is the wind turbine hub height, $Z_{\text {anem }}$ is the anemometer height, and a is the power law exponent.

$$
\mathbf{P}_{\text {Wout }}=\frac{1}{2} * \mathbf{\rho} * \mathbf{A} * \mathbf{V} * \mathbf{C}_{\mathbf{p}} * \eta_{\mathbf{t}} * \eta_{\mathbf{g}}
$$

where $\mathrm{r}$ is the air density, $\mathrm{A}$ is the rotor area in $\mathrm{m} 2, \mathrm{~V}$ is wind velocity in $\mathrm{m} / \mathrm{s}, \mathrm{Cp}$ is performance density of air coefficient of the turbine and ht and hg are the efficiencies of wind turbine and the generator, respectively. The initial cost according to the Moroccan market of the wind turbine unit is considered as $\$ 10,775$ with the replacement cost of $\$ 0$ considering the equality between the project life and the wind turbine lifespan and the operation and maintenance cost of $20 \$ / y e a r$.

\subsection{Biogas generator}

The gasification reaction takes place under very high temperature conditions (>1000 C) (Heydari and Askarzadeh, 2016). Syngas is used as a source of electricity production from gas turbines. In this case, the cost of fuel is not considered because the fuel is the animal waste, which can be found abundantly. The initial price of biomass generator is taken as $1600 \$ / \mathrm{kW}$, the replacement and operating costs are assumed as $1250 \$ / \mathrm{kW}$ and $0.1 \$ / \mathrm{h}$, respectively. The life of the biogas generator is taken as $20,000 \mathrm{~h}$ so as the lower heating value of $5.5 \mathrm{MJ} / \mathrm{kg}$, and the percentage carbon content as $5 \%$.

\subsection{Converter}

The converters are among the most important components of the hybrid system utilized to convert alternating current (AC) to direct current (DC) or the opposite way. To do this, it is placed between the AC and DC segments. The efficiency of the latter relies on the other devices of the hybrid system (Eroglu et al., 2011). In the present case, the initial, replacement, and maintenance costs per $\mathrm{kW}$ capacity are taken as $\$ 400, \$ 400$, and $\$ 0$ per year, respectively. The lifetime of the converter is taken as 15 years. Efficiency of the inverter and rectifier are considered as $90 \%$ and $95 \%$, respectively. 


\subsection{Battery}

In hybrid systems, which are not usually connected to the electricity network, batteries play an important role as they ensure the continuous power supply during the periods when there is no or inadequate electricity production and maintain constant voltage during the peak demanding of irrigation . The storage capacityof the battery, Bc, is calculated using equation (8) (Malheiro et al., 2015). In equation (8), Dele is the daily electrical demand in [kWh/day].the daily electrical demand in [kWh/day], Dd is the depth of discharge of the battery, Na is the daily range $\mathrm{Na}$ is the daily autonomy, and hb and hinv are the efficiencies of the battery and converter, respectively.

In this work, the battery employed has a capacity of $167 \mathrm{Ah}$ with a nominal voltage of $6 \mathrm{~V}$. The capital cost and the replacement cost in Moroccan market of this battery is $\$ 330$, the maintenance cost is equal to 10 \$/year, with the expected lifetime of 15 years. Table 1 summarizes the specifications of the selected battery.

\section{Simulation process and economic considerations}

For the economic analysis, the life of the project is equal to 25 years; the discount rate and inflation rate are considered as $5 \%$ and $2.5 \%$, respectively (Allouhi et al., 2016). Table3 summarizes the capital, replacement, and operating and maintenance (O\&M) fees for each component of the hybrid system.

\subsection{Net present cost}

The hybrid power system optimization tool, HOMER, is exploited to optimize the system rested on the minimum net present cost (NPC) that can be evaluated as follows.

$$
\mathrm{C}_{\mathrm{NPC}}=\mathrm{U}_{\mathrm{anem}} *\left(\frac{\mathrm{C}_{\text {ann,tot }}}{\mathrm{CRF}_{(\mathrm{i}, \mathrm{Rproj})}}\right)
$$

With

$$
C R F=\frac{\mathrm{i} *(1+\mathrm{i})^{N}}{(1+\mathrm{i})^{N}-1}
$$

where Cann tot and CNPC represent total annualized cost (\$/year) and total net cost $(\$)$, CRF is the capital recovery factor, Rproj is the project life time in years and $\mathrm{i}$ is the interest rate $(\%)$.

\subsubsection{Levelized cost of electricity}

The levelized COE is a very important indicator for economic analysis of any hybrid system. The COE means the cost of a kWh electricity generated by the system. The COE is calculated by Homer by dividing total annualized cost (TAC) with respect to the total annualized primary served load (kWh/yr) Eprim, as following:

$$
\begin{gathered}
T A C=\mathrm{NPC} \times \operatorname{CRT}(\mathrm{i}, \mathrm{N})[32] \\
\mathrm{C}_{\mathrm{NPC}}=\frac{T A C}{E_{\text {Prim }}} \quad[33]
\end{gathered}
$$

Table 2. Properties of the selected battery.

\begin{tabular}{ll} 
Properties & Specifications \\
\hline Nominal voltage & $6 \mathrm{VDC}$ \\
Nominal capacity & $167 \mathrm{Ah}$ \\
Roundtrip efficiency & $90 \%$ \\
Maximum charge current & $167 \mathrm{~A}$ \\
Maximum discharge current & $500 \mathrm{~A}$ \\
lifespan & 15 years \\
\hline
\end{tabular}


Table 3. Information regarding Hybrid power system components.

\begin{tabular}{|c|c|c|c|c|c|}
\hline \multirow[t]{2}{*}{ Parameters } & \multicolumn{5}{|l|}{ Components } \\
\hline & PV & Wind $\mathrm{B}$ & $\begin{array}{l}\text { Biomass } \\
\text { Generator }\end{array}$ & Battery & Converter \\
\hline & $1 \mathrm{~kW}$ & $1 \mathrm{~kW}$ & $1 \mathrm{~kW}$ & I Unit & $1 \mathrm{~kW}$ \\
\hline Capital cost (\$) & 1600.00 & $\begin{array}{c}2155.0 \\
0\end{array}$ & $\begin{array}{c}1600.0 \\
0\end{array}$ & 330.00 & 400.00 \\
\hline $\begin{array}{l}\text { Replacement cost } \\
\text { (\$) }\end{array}$ & 0.00 & 0.00 & $\begin{array}{c}1250.0 \\
0\end{array}$ & 330.00 & 400.00 \\
\hline $\begin{array}{l}\text { O \& M cost } \\
\text { (\$/year) }\end{array}$ & 15.00 & 20.00 & 876.00 & 10.00 & 0.00 \\
\hline Life-time, (years) & 25 & 25 & 2.28 & 15 & 15 \\
\hline Efficiency, (\%) & $\mathrm{e}$ & $\mathrm{e}$ & $\mathrm{e}$ & 90 & 95 \\
\hline Current type & DC & $\mathrm{AC}$ & $\mathrm{AC}$ & $\mathrm{e}$ & $\mathrm{e}$ \\
\hline
\end{tabular}

\subsubsection{Compared to a scenario of diesel power generation.}

The second approach quantifies the amount of avoided $\mathrm{CO}_{2}$ emissions comparing with the scenario of diesel-based power generation. Homer calculates $\mathrm{CO}_{2}$ emissions caused by a diesel

$$
\mathrm{EM}_{\mathrm{AV}, \mathrm{DG}}=\left(3.667 * \mathrm{~m}_{\mathrm{f}} * \mathrm{HV}_{\mathrm{f}} * \mathrm{X}_{\mathrm{f}} * \mathrm{CEF}_{\mathrm{f}}\right)-\mathrm{EM}_{\mathrm{HRES}}
$$

where $\mathrm{mf}$ represents the fuel volume (liter), $\mathrm{HVf}$ refers to the calorific number of the fuel (MJ/L), Xf means fraction of the oxidized carbon and CEFf means the carbon emission factor (tonne of car-bon/TJ), EMHRES and means the emissions emitted by the system.

In this work, a hybrid system is designed and its performance characteristics are carefully examined to successfully fulfil the energy demand of the studied area. The proposed hybrid power system is optimized using HOMER, which delivers outcomes regarding the system optimization, performance and sensitivity analysis. HOMER identifies the optimum configuration of the off-grid taking into account the solar, wind and biomass renewable energy sources.

HOMER performs simulations to describe the operation of each possible configuration by considering energy balance computations in each time step. At each time, HOMER predicts the energy demand to the corresponding energy from the proposed system, and evaluates the flows of energy between whether to charge/discharge the batteries. According to the computations, HOMER indicates whether a configuration is viable first in terms of satisfying the electric load under the given conditions. Then, it gives a detailed financial evaluation of costs during the whole project lifetime. As such, for each possible configuration, HOMER sorts by net present cost of the investigated options and indicates optimum scenarios inducing lowest life cycle expenditures. Table 5 describes the different scenarios examined by the simulation process.

\subsection{HRES optimization results}

Table 4 shows the possible configurations of supplying the electric load to the studied zone based on the available energy sources. It also indicates design options and installed capacities with respect to each configuration.

The most cost-effective system (Scenario A), as described in Table 5, consists of PV-Wind-Biomass-Battery as it yields the lowest Net Present Cost (NPC) of $\$ 123,887.00$ and accordingly the lowest Cost of Energy (COE) of $0.2 \$ / \mathrm{kWh}$, respectively.

Switching to scenario B that excludes the utilization of wind power does not generate a considerable difference in NPC at around $2.18 \%$. As seen, Scenario B is characterized by a larger PV field to substitute energy production from the wind turbine as compared to scenario A.

The use of wind energy, photovoltaic panels and the battery(scenario C) will generate an additional NPC of $74.4 \%$. The NPC of scenarios D, E and F remains costly options compared to scenario A. All scenarios have 100\% renewable fraction since there is no diesel or other engine. Under unmet load and excess production, scenario E presents $0 \mathrm{kWh} / \mathrm{yr}$ 
for unmet load with an excess production of the order of $253 \mathrm{kWh} / \mathrm{yr}$. Following, scenario A has unmet load and excess production $21.4 \mathrm{kWh} / \mathrm{yr}$ and $2071 \mathrm{kWh} / \mathrm{yr}$,respectively.

The last scenario engenders the higher annual electricity production that surplus is estimated to be $52,605 \mathrm{kWh} / \mathrm{year}$. In the rest of the discussion, the scenario A consisting of the Solar-Wind-Bio sources will be analysed, forming the optimum HRES configuration. Such a configuration is of a particular interest, particularly for guiding strategic policies for diversifying energy mixes.

\subsection{Analysis of the optimum scenario (A)}

The capital cost, the NPC, and operations costs of the suggested system (scenario A) which contains PV-Wind-BiomassBattery are found to be $\$ 49,524, \$ 123,887$, and $\$ 4,008$, respectively. The levelized (COE) is considered to be $0.2 \$ / \mathrm{kWh}$ . The scenario A consists of a wind turbine with $5.1 \mathrm{~kW}$ capacity, $9.11 \mathrm{~kW}$ of PV panel, $3 \mathrm{~kW}$ of biomass generator, 53 $167 \mathrm{Ah}$ of accumulator, $4.7 \mathrm{~kW}$ converter with the strategy of cycle charging load. This optimal configuration emits about $9.58 \mathrm{~kg} /$ year of $\mathrm{CO}_{2}$. Table 6 shows the pollutants and their concentrations for the optimal configuration. The very low quantity of $\mathrm{CO}_{2}$ emissions can be attributed to the fact that the proposed system does not contain non-renewable energy sources.

Table 4. Proposed HRES for application in study site.

\begin{tabular}{|l|l|}
\hline Proposed HRES & Scenario \\
\hline PV/Wind/Biomass/Battery & A \\
PV/Biomass/Battery & B \\
PV/Wind/Battery & C \\
PV/Battery & D \\
Wind/Biomass/Battery & E \\
Wind/Battery & F \\
\hline
\end{tabular}

Table 5. Comparison of different scenarios based on simulation results

\begin{tabular}{|c|c|c|c|c|c|c|}
\hline Scenario & A & B & $\mathrm{C}$ & $\mathrm{D}$ & $\mathrm{E}$ & $\mathrm{F}$ \\
\hline $\mathrm{PV}(\mathrm{kW})$ & 9.11 & 14.3 & 46.0 & 46.7 & 0 & 0 \\
\hline $\begin{array}{l}\text { Wind AWS } 5.1 \\
\text { kW }\end{array}$ & 1 & 0 & 3 & 0 & 3 & 20 \\
\hline Biomass (kW) & 3 & 3 & 0 & 0 & 3 & 0 \\
\hline Battery $1 \mathrm{kWh}$ & 53 & 54 & 134 & 235 & 276 & 447 \\
\hline Converter kW & 4.7 & 5.26 & 7.37 & 8.52 & 4.07 & 19.9 \\
\hline $\operatorname{COE}(\$)$ & 0.200 & 0.205 & 0.349 & 0.411 & 0.477 & 0.875 \\
\hline NPC (\$) & 123,887 & 126,595 & 216,099 & 253,977 & 295,353 & 541,278 \\
\hline O\&M (\$) & 4008 & 4261 & 3397 & 5295 & 8921 & 9179 \\
\hline Capital cost (\$) & $49,524.40$ & 47,538 & 153,073 & 155,742 & 192,834 & 370,980 \\
\hline $\begin{array}{l}\text { Production } \\
\text { (kWh/year) } \\
\text { excess } \\
\text { production } \\
\text { (kWh/year) }\end{array}$ & 36,974 & 42,278 & 88,745 & 77,493 & 34,851 & 83,334 \\
\hline
\end{tabular}




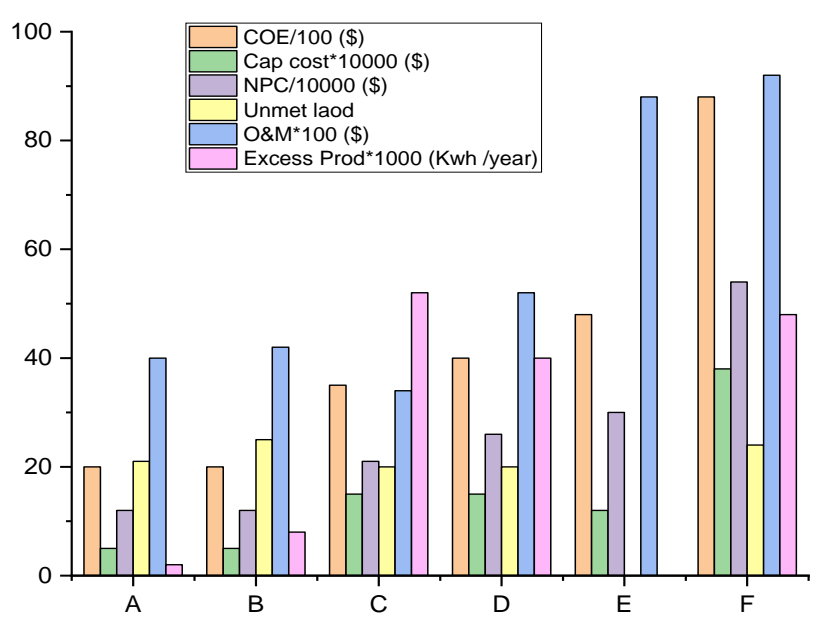

Figure 16 : Configuration of the proposed hybrid power system

Table 6. Pollutant emissions corresponding to the optimal configuration.

\begin{tabular}{|c|c|}
\hline Types of polluting greenhouse gases & Value $(\mathrm{kg} /$ year $)$ \\
\hline Carbon dioxide $\left(\mathrm{CO}_{2}\right)$ & 9.85 \\
Carbon monoxide $(\mathrm{CO})$ & 0.106 \\
Unburned hydrocarbons & 0 \\
Particulate matter & 0 \\
Sulfur dioxide $\left(\mathrm{SO}_{2}\right)$ & 0 \\
Nitrogen oxides $\left(\mathrm{NO}_{2}\right)$ & 0.0664 \\
\hline
\end{tabular}

\subsubsection{Electricity production and economic}

analysis for system A Fig. 17 illustrates the monthly average energy generation produced by scenario A. It is observed that the average monthly electricity generation is nearly constant for the biogas generator and solar panels throughout the year. Solar energy generation experiences a slight decrease in October, November, December and January (rainy season with low radiation values, rain and overcast conditions) and the maximum generation is reached in June and July (peak of the summer season ). For the production of electricity generated by biomass decreases in June/July and its maximum is predicted in December.

The relative contribution of each component is as $11 \%$ of wind power, $41 \%$ of solar power and $48 \%$ of biomass power, respectively. The biomass generates more power with annual pro-duction of $17,701.00 \mathrm{kWh}$ than other components in the proposed system. PV panels have annual energy contribution of 15,106.00 kWh. The lowest amount of energy is derived from the WT, which is envisaged to be $4167.00 \mathrm{kWh}$. Table 5 shows that there is energy surplus totalling of $2071 \mathrm{kWh}$, that is to say $5.6 \%$ of overall production. This excess energy can be used to support the increasing energy needs of the farmers (household appliances, greenhouses , ...). Unmet load electric for this scenario is around 21.4 $\mathrm{kWh} / \mathrm{yr}$, (equivalent to $0.0642 \%$ ) which is insignificant value proving the effectiveness of the proposed architecture. 


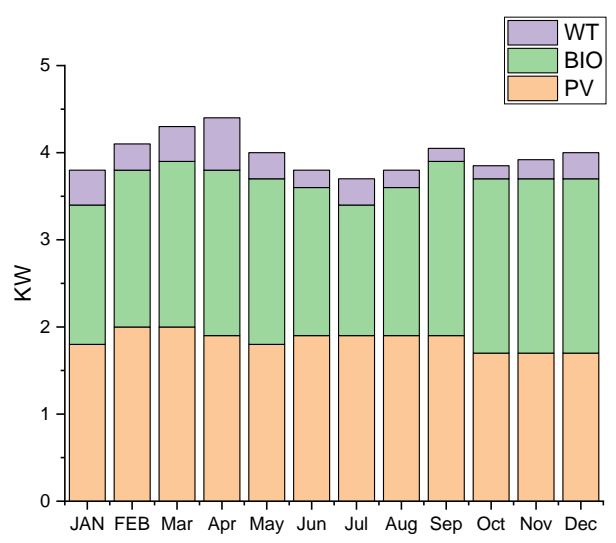

Figure 17: Electrical power generation of scenario A

As for the corresponding cost figures, Table 7 provides the capital, replacement, O\&M, and salvage costs for each element of the hybrid energy system which are found to be $\$ 49,524.40, \$ 32,779.54$, and $\$ 46,142.01$, respectively.

\subsection{Sensitivity analysis}

In this study, for a complete technical-economic evaluation of the proposed HRES (scenario A), it is critical to carry out sensitivity analyses on key operating/financial parameters. The first sensitivity deals with the impact of the variation of the discount rate and the inflation rate on the cost of energy and the net present cost of the system. Both parameters were varied from $0 \%$ to $10 \%$ with an increment of $0.5 \%$.

The cost of electricity (COE) generated by the system hybrid (PV/ Wind/Biomass/Battery) is illustrated in a surface plot as shown in Fig.19. The discount rate (\%) is taken along $\mathrm{x}$-axis and the inflation rate (\%) along $\mathrm{y}$-axis. According to this figure, the inflation rate and discount rate have an influential effect on the economic performance of the HRES. In other words, by increasing the inflation rate and decreasing the discount rate decreases the unit cost of the energy produced (Nyeche and Diemuodeke, 2020).

The second sensitivity study is to evidence the effect of capital cost reduction on the HRES financial performance. The initial cost

\subsection{Environmental and carbon market analysis}

Morocco was committed to COP21 to reduce its GHG emissions in 2030 by $40 \%$ compared to projected emissions by 2030. This goal corresponds to a cumulative reduction of $523.5 \mathrm{Mt} \mathrm{CO}_{2}$-eq over the period between 2020 and 2030 . The integration of systems based on renewable sources to produce electricity is vital to reduce greenhouse gas emissions and fossil fuel based resources (Anvari et al., 2018). Quantification of $\mathrm{CO}_{2}$ emissions avoided by the proposed system is introduced and compared to the different power generation modes.

\subsubsection{Scenario based on grid extension}

The avoided $\mathrm{CO}_{2}$ emissions that can arise from replacing grid electrification by the PV-wind-biomass system arecalculated based on Eq. (34). The quantity of $\mathrm{CO}_{2}$ emissions in this case was esti-mated to be around 26.48 tonnes of $\mathrm{CO}_{2}$ per year.

\subsubsection{Scenario based on diesel power generation}

An additional simulation was carried out considering the same electric demand at the same region. The proposed system contains a non-renewable energy source consisting of the DG-battery to assess the $\mathrm{CO}_{2}$ emissions avoided due to the utilization of The hybrid system based on renewable energy resources. The capital cost and the replacement cost of the diesel generator are consid-ered as $300 \$ / \mathrm{kW}$ while the maintenance cost is taken equal to $0.03 \$$ hours.

The simulation results are illustrated in Table 7 (Scenario 1). It is an interesting configuration since it allows assessing the amount of $\mathrm{CO}_{2}$ avoided by the PV-Wind-Biomass Battery system discussed above. That is to say, the production of 


\section{Research Article}

electricity in this case will only be ensured by the diesel generator.In addition to the environmental damage that will be caused by this system, the price of the electricity produced is equal to 0.354 .

Table 7. Annual electricity production of hybrid system and consumption.

\begin{tabular}{|c|c|c|c|c|c|}
\hline Component & Capital (\$) & Replacement (\$) & O\&M (\$) & Salvage (\$) & Total (\$) \\
\hline Battery & $17,490.00$ & $12,184.52$ & 9833.37 & 3191.78 & $36,316.11$ \\
\hline Bio-Generator & 4800.00 & $19,284.17$ & $33,401.92$ & 1023.95 & $56,462.14$ \\
\hline Converter & 1881.64 & 1310.85 & 0.00 & 343.38 & 2849.11 \\
\hline PV & $14,577.76$ & 0.00 & 2535.65 & 0.00 & $17,113.41$ \\
\hline Wind-turbine & 10775.00 & 0.00 & 371.07 & 0.00 & 11146.07 \\
\hline System & $49,524.40$ & $32,779.54$ & $46,142.01$ & 4559.11 & $123,886.83$ \\
\hline
\end{tabular}

Table 8. Summary of various costs related to the PV-Wind-Biomass-Battery hybrid system.

\begin{tabular}{ccccc} 
Technology & Energy production $\mathrm{kWh} / \mathrm{year}$ & Energy contribution $(\%)$ & Load Type & Energy consumption kWh/year \\
\hline PV & $15,106.00$ & 41.00 & AC primary load & $33,332.00$ \\
Biomass & $17,701.00$ & 48.00 & DC primary load & 0.00 \\
Wind & 4167.00 & 11.00 & Total & $33,332.00$ \\
Total & $36,974.00$ & 100.00 & & \\
\hline
\end{tabular}

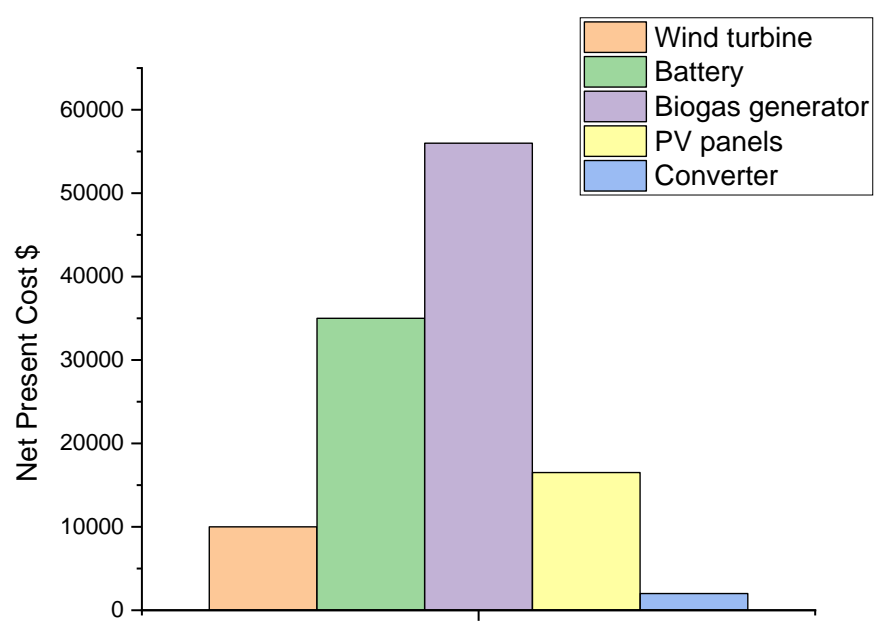

Figure 18: Cash flow summary of each energy components

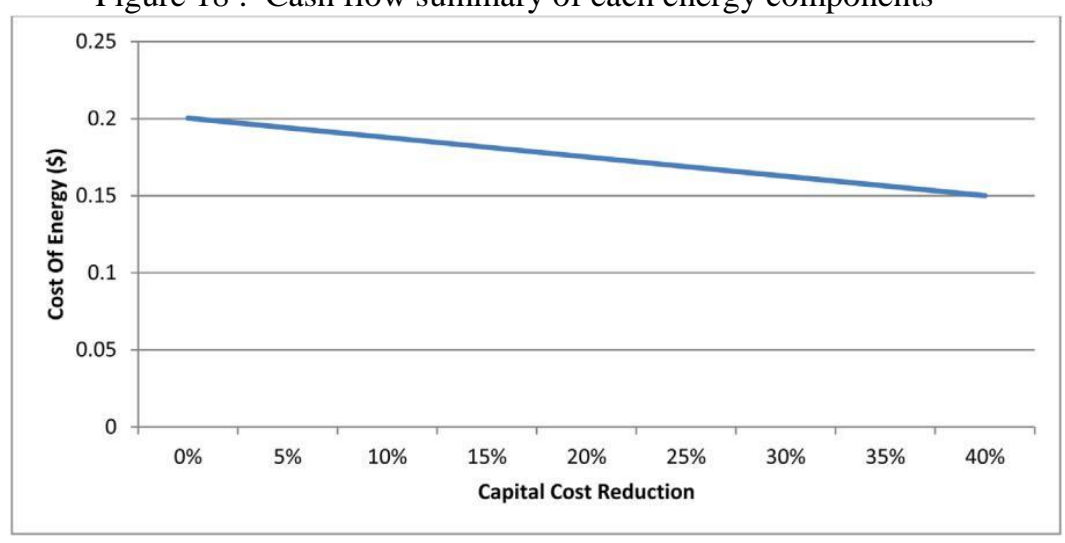

Figure 19: impact of the capital cost reduction on COE of the system 
Table 9. Summary of DG-Battery system.

\begin{tabular}{|c|c|c|c|}
\hline $\begin{array}{l}\text { Components/Para } \\
\text { meters }\end{array}$ & Unit & $\begin{array}{c}\text { Without introducing a penalty for } \mathrm{CO}_{2} \\
\text { emissions (Scenario 1) }\end{array}$ & $\begin{array}{c}\text { With introducing a penalty for } \mathrm{CO}_{2} \\
\text { emissions (Scenario 2) }\end{array}$ \\
\hline $\mathrm{DG}$ & $\mathrm{kW}$ & 7.1 & 7.1 \\
\hline Converter & $\mathrm{kW}$ & 3.33 & 3.33 \\
\hline Battery & Qty & 17 & 17 \\
\hline Net present cost & $\$$ & 128,962 & 230,193 \\
\hline \multicolumn{4}{|c|}{$\$ / \mathrm{kW}$} \\
\hline Cost of energy & $\mathrm{h}$ & 0.354 & 0.372 \\
\hline Operating cost & $\$$ & 11,313 & 11,318 \\
\hline $\begin{array}{l}\text { Renewable } \\
\text { fraction }\end{array}$ & $\%$ & 0 & 0 \\
\hline Initial capital & $\$$ & 9073 & 9073 \\
\hline
\end{tabular}

\section{Conclusion :}

The monitoring of agricultural fields in terms of production and irrigation water management efficiency at the regional level can be based on the extraction of information from satellite images through the temporal dynamics of biophysical variables that affect crop photosynthesis. The annual NDVI LANDSAT series has been processed according to the classification based on the pixel approach.

The results showed the ability of this methodology to discriminate between cultures.

converting to renewable energy in the world in general and in Morocco in particular via several projects such as the Moroccan green plan and green generation in irrigation has become an essential solution, it is in this perspective that we have made a technical study to evaluate first the need for electricity to ensure an irrigation demand and without interruption of six crops in the region of GHarb as shown on the map, and a technical-economic study to evaluate the different variants available.

Simulation and analysis results showed that with an average daily energy demand of $92 \mathrm{kWh}$ and a peak load of 6.5 $\mathrm{kW}$, the energy cost of the optimal configuration (scenario A) is $\$ 0.19 / \mathrm{kWh}$. This cost increases from scenario A to scenario F. Therefore, option A is the most cost-effective and is chosen as the optimal configuration. For the biomasswind-PV-battery option A, it was shown that the initial investment cost, maintenance cost, NPC and electricity cost are $\$ 49,524.40, \$ 4,008, \$ 123,887$ and $\$ 0.2 / \mathrm{kWh}$ respectively. These are competitive figures that outperform the other alternatives studied.

\section{References}

[1]Allen and al., 2006. Crop Evapotranspiration: Guidelines for Computing Crop Water Requirements. Irrigation and DrainagePaper 56. FAO, Rome, Italy.

[2] Allen, R.G., Pereira, L.S., Howell, T.A., Jensen, M.E., 2011. Evapotranspiration information reporting: I: factors governing measurements accuracy. Review.Agric. Water Manag. 98, 899-920.

[3] Quarmby and al., 1993. The use of multi-temporal NDVI measurements from AVHRR data for crop yield estimation and prediction. Int. J. Remote Sens. 14 (2), 199-210. https://doi.org/10.1080/01431169308904332

[4] Rouse and al. The 3rd earth resources technology satellite-1 symposium, Greenbelt, MD, pp. 309-317. SantinJanin, H., Garel, M., Chapuis, J.L., Pontier, D., 2009. Assessing the performance of NDVI as a proxy for plant biomass using non-linear models: a case study on the Kerguelen archipelago. Polar Biol. 32 (6), 861-871.

[5] Bharathkumar and Mohammed-Aslam 2015. INTERNATIONAL CONFERENCE ON WATER RESOURCES, COASTAL AND OCEAN ENGINEERING (ICWRCOE 2015) Crop Pattern Mapping of Tumkur Taluk using NDVI Technique: A Remote Sensing and GIS Approach 
[6] Kuenzer, Claudia; Knauer, Kim (2013). Remote sensing of rice crop areas. International Journal of Remote Sensing, 34(6), 2101-2139. http://dx.doi.org/10.1080/01431161.2012.738946

[7] Doorenbos, J., 1984. Guidelines for Predicting Crop Water Requirement Irrigation and drainage paper 24. Food and Agriculture Organization of the United Nations, Rome.

[8] Ding, R., Kang, S., Zhang, Y., Hao, X., Tong, L., Du, T., 2013. Partitioning evapotranspiration into soil evaporation and transpiration using a modified dual crop coefficient model in irrigated maize field with groundmulching. Agric. Water Manag. 127, 85-96. https://doi.org/10.1016/j.agwat.2013.05.018[9] Doraiswamy et al., September 2004. Crop condition and yield simulations using Landsat and MODIS, Remote Sensing of Environment 92(4), DOI: 10.1016/j.rse.2004.05.017

[10] Bell, G.E., Martin, D.L., Koh, K., Han, H.R., 2009. Comparison of turfgrass visual quality ratings with ratings determined using a handheld optical sensor. HortTechnology $19 \quad$ (2), 309-316. https://doi.org/10.1016/j.agwat.2020.106586

[11] Doorenbos, J., Pruitt, W.O., 1977. Crop Water Requirements, FAO Irrigation and Drainage Paper No. 24. Food and Agriculture Organization, Rome, Italy.

[12] Ray, S.S., Dadhwal, V.K., 2001. Estimation of crop evapotranspiration of irrigation command area using remote sensing and GIS. Agric. Water Manage. 49, 239-249. Rosenstein, O., Haymann, N., Kaplan, G., Tanny, J., 2018. Estimating cotton water consumption using a time series of Sentinel-2 imagery. Agric. Water Manage. 207, 44-52.

[13] Justice, C.O., Townshend, J.R.G., 2002. Special issue on the Moderate Resolution Imaging Spectroradiometer (MODIS): a new generation of land surface monitoring. Remote Sens. Environ. 83 (1), 1-2

[14] Boegh, E., Søgaard, H., Hanan, N., Kabat, P., Lesch, L., 1999. A remote sensing study of the NDVI-Ts relationship and the transpiration from sparse vegetation in the Sahel based on high-resolution satellite data. Remote Sens. Environ. 69 (3), 224-240 1

[15] Hunsaker, D.J., Barnes, E.M., Clarke, T.R., Fitzgerald, G.J., Pinter, P.J., 2005. Cotton irrigation scheduling using remotely sensed and FAO-56 basal crop coefficients. Trans. ASAE 48, 1395-1407

[16]. Batchelor C.H., Roberts J., Evaporation from the irrigation water, foliage and panicles of paddy rice in northeast Sri Lanka, Agric. Meteorol. 29 (1983) 11-26.

[18] Penman, H.L., 1948. Natural evaporation from open water, bare soil, and grass. Proceedings of the Royal Society of London A: Mathematical, Physical and Engineering Sciences. The Royal Society. pp. 120-145

[19] Thornthwaite, C.W., 1948. An approach toward a rational classification of climate. Geogr. Rev. 38, 55-94.

[20] Nouri, H., Glenn, E.P., Beecham, S., Chavoshi Boroujeni, S., Sutton, P., Alaghmand, S., Noori, B., Nagler, P., 2016. Comparing three evapotranspiration estimation approaches in mixed urban vegetation: field-based, remote sensing-based, and observational-based methods. Remote Sens. (Basel) 8, 492.

[21] Irmak, S., Odhiambo, L.O., Specht, J.E., Djaman, K., 2013. Hourly and daily single and basal evapotranspiration crop coefficients as a function of growing degree days after emergence, leaf area index, fractional green canopy

[22] L.S. Pereira, Prediction of crop coefficients from the fraction of ground cover and height. Background and validation using ground and remote sensing data. 
https://doi.org/10.1016/j.agwat.2020.106197

[23] E. Farg and al., Estimation of Evapotranspiration ETc and Crop Coefficient Kc of Wheat, in south Nile Delta of Egypt Using integrated FAO-56 approach and remote sensing data, 2012, 15, 83-89. http://dx.doi.org/10.1016/j.ejrs.2012.02.001

[24] Hunsaker, D.J.; Pinter, P.J.; Jr.; Kimball, B.A. Wheat basal crop coefficients determined by normalized difference vegetation index. Irrig. Sci. 2005, 24, 1-14.

[25] Bausch, W.C.; Neale, C.M.U. Spectral inputs improve Maize crop coefficients and irrigation scheduling. Trans. ASAE 1989, 32, 1901-1908.

[26] Irmak, S. Nebraska water and energy flux measurement, modeling, and research network (NEBFLUX). Trans. ASABE 2010, 53, 1097-1115.

[27] Allouhi, A., Saadani, R., Kousksou, T., Saidur, R., Jamil, A., Rahmoune, M., 2016. Grid-connected PV systems installed on institutional buildings: technology com-parison, energy analysis and economic performance. Energy Build. 130, 188e201.

[28] Almutairi, A.S., Pilidis, P., Al-Mutawa, N., 2016. Exergetic, exergoeconomic and exergoenvironmental analysis of intercooled gas turbine engine. In: 52nd AIAA/ SAE/ASEE Joint Propulsion Conference, p. 5060.

[29] Amutha, W.M., Rajini, V., 2015. Techno-economic evaluation of various hybrid po-wer systems for rural telecom. Renew. Sustain. Energy Rev. 43, 553e561. Anvari, S., Khalilarya, S., Zare, V., 2018. Exergoeconomic and environmental analysis of a novel configuration of solar-biomass hybrid power generation system. Energy 165, $776 \mathrm{e} 789$.

[30] Baseer, M.A., Alqahtani, A., Rehman, S., 2019. Techno-economic design and evalu-ation of hybrid energy systems for residential communities: case study of Jubail industrial city. J. Clean. Prod. 237, 117806.

Billinton, R., 2005. Evaluation of different operating strategies in small stand-alone power systems. IEEE Trans. Energy Convers. 20, 654e660.

[31] Buker, M.S., Mempouo, B., Riffat, S.B., 2014. Performance evaluation and techno-economic analysis of a novel building integrated PV/T roof collector: an experimental validation. Energy Build. 76, 164e175.

[32] El-Houari, H., Allouhi, A., Rehman, S., Buker, M.S., Kousksou, T., Jamil, A., El Amrani, B., 2019. Design, simulation, and economic optimization of an off-grid photovoltaic system for rural electrification. Energies 12. https://doi.org/ 10.3390/en12244735.

[33] Eroglu, M., Dursun, E., Sevencan, S., Song, J., Yazici, S., Kilic, O., 2011. A mobile renewable house usin PV/wind/fuel cell hybrid power system. Int. J. Hydrogen Energy 36, 7985e7992.

Halabi, L.M., Mekhilef, S., Olatomiwa, L., Hazelton, J., 2017. Performance analysis of hybrid PV/diesel/battery system using HOMER: a case study Sabah, Malaysia. Energy Convers. Manag. 144, 322e339.

[34] Hossain, A.K., Badr, O., 2007. Prospects of renewable energy utilisation for electricity generation in Bangladesh. Renew. Sustain. Energy Rev. 11, 1617e1649.

[35] Kennedy, N., Miao, C., Wu, Q., Wang, Y., Ji, J., Roskilly, T., 2017. Optimal hybrid power system using renewables and hydrogen for an isolated island in the UK. Energy Procedia 105, 1388e1393. 